\title{
ASSIMILATION AS AN EFFORT TO OVERCOME THE SPREAD OF CORONA VIRUS ACCORDING TO MINISTER OF LAW AND HUMAN RIGHTS REGULATION NO.24 OF 2021
}

\author{
Hijriyana Safithri ${ }^{1}$, Ramiah Lubis ${ }^{2}$
}

\begin{abstract}
The corona virus has become a global epidemic since the last two years, and Indonesia is also included in the country affected by this corona virus outbreak, especially in 2021 the corona virus outbreak is increasing, taking so many victims. Therefore, the Ministry of Law and Human Rights has extended the policy of granting assimilation rights at home for prisoners and children to reduce the density of prisoners in prisons, state detention centers and the Special Child Development Institute (LPKA). The problem is for prisoners, what are the conditions that must be met to obtain assimilation at home and what if the prisoners who have received assimilation at home commit crimes again during the assimilation period at home. The method used in this paper is a qualitative research method. That is by collecting legal materials by reading, quoting, taking notes, and studying reading materials related to research problems, especially the Regulation of the Minister of Law and Human Rights no. 24 of 2021 amendments to Ministerial Regulation Number 32 of 2020 concerning Conditions and Procedures for Granting Assimilation, Conditional Release, Leave Before Release, and Conditional Leave for Convicts and Children in the Context of Prevention and Control of the Spread of Covid-19. The data that has been collected is stated in the form of a description. The data analysis used in this research is descriptive qualitative. Prisoners will obtain assimilation if they have met the requirements contained in Article 11 and Article 45 of the Regulation of the Minister of Law and Human Rights No. 24 of 2021 and if the prisoner commits a crime while carrying out assimilation at home, he will be subject to a heavier sentence than before.
\end{abstract}

Keywords: Covid-19, Prisoners, Assimilation

\section{The Introduction}

Since the last two years, the world is currently being hit by an epidemic whose name is the corona virus, Indonesia is also included in the country affected by this corona virus outbreak, especially in 2021 the corona virus outbreak is increasing, taking so many victims. The Corona virus, also known as COVID-19, can attack anyone. According to data released by the Task Force for the Acceleration of Handling COVID-19 of the Republic of Indonesia, the number of confirmed positive cases as of May 3, 2021 is $1,677,274$ people with a death toll of 45,796 people. The case fatality rate due to COVID-19 is around $2.7 \%$. When viewed from the percentage of death rates divided by age group, the 46-59 year age group has a higher percentage of death rates than other age groups. Meanwhile, based on gender, 56.6\% of

1 Faklutas Syariah dan Hukum UIN Raden Fatah Palembang, Email: hijriyanasafithri_uin@radenfatah.ac.id

2 Faklutas Syariah dan Hukum UIN Raden Fatah Palembang, Email. ramiahlubis_uin@radenfatah.ac.id 
patients who died from COVID-19 were male and the remaining $43.4 \%$ were female. (Pane, 2021) The Indonesian government has declared the Corona Virus or Covid 19 outbreak as a national disaster since March 14, 2020, which was announced by the President through the Head of the National Disaster Management Agency based on Law Number 24 of 2007. Urges on the government to immediately take strategic steps to provide protection against Indonesian people in general and medical personnel in particular from the ferocity of the Corona Virus or Covid 19 pandemic continues to roll. Until now, the government continues to work hard in providing health protection guarantees from the Corona Virus or Covid 19 pandemic. In order to provide this guarantee, one of the efforts made by the government in suppressing the rate of transmission of the Corona Virus or Covid 19 is issuing policies in the form of granting assimilation and rights. integration for prisoners and children through Minister of Law and Human Rights Regulation No. 10 of 2020 and the Decree of the Minister of Law and Human Rights No. 19/PK/01/04/2020. This policy was taken with careful consideration that almost all correctional institutions and detention centers in the country are overcapacity so they are vulnerable to the threat of the Corona Virus or Covid 19 pandemic and are in accordance with the Large-Scale Social Restriction policy. (Anwar, 2020)

Everyone has a different response to COVID-19. Most people who are exposed to this virus will experience mild to moderate symptoms, and will recover without needing to be hospitalized. Corona virus or severe acute respiratory syndrome coronavirus 2 (SARS-CoV-2) is a virus that attacks the respiratory system. The disease caused by this viral infection is called COVID-19. Corona virus can cause mild disorders of the respiratory system, severe lung infections, and even death. This virus can attack anyone, such as the elderly (older groups), adults, children, and infants, including pregnant women and breastfeeding mothers. This has made several countries implement policies to impose lockdowns in order to prevent the spread of the Corona virus. In Indonesia itself, President Joko Widodo has recently officially issued a policy for the Enforcement of Emergency Community Activity Restrictions (PPKM) to tighten community activities in preventing the increasingly widespread spread of Covid-19. The policy was announced on Thursday (1/7/2021) at the Presidential Palace. Previously, the government also imposed a PPKM regulation which was implemented on a micro scale on June 1, 2021. (Rosa, 2021) The development of punishment in Indonesia has undergone several changes. First, as a Retribution/Restraint tool, which in its operation uses low pressure on society and low pressure on individuals. This means that they pay less attention to individual interests and pay less attention to the interests of the community. Second, prison as a means of deterrence, using a model of high pressure on society and low pressure on individuals by using a deterrent method. This means that the interests of the community are prioritized over individual interests. Third, prison as a rehabilitation tool uses a model of low pressure on society and high pressure on individuals. This means that the focus of attention is more directed at individual offenders, while the community is less involved in the repair process. Fourth, Prison as a means of Re-integration, namely restoring relations with the community, using a high pressure model on society and 
high pressure on individual offenders. It means focus of attention equally high, both to the community and to individual violations.

Sentencing in prison is indeed a form of criminal execution. The place of execution of the prison sentence has changed the term to Correctional Institution.The judge who is more dominant to pass the sentence imprisonment turned out to have a very significant impact on increasing the number of prisoners in correctional institutions.Indonesia is a state of law, in the criminal justice system in Indonesia to carry out crimes for lawbreakers in prison.Penitentiary is "a directorate located at the Ministry of Law and Human Rights to foster and guide lawbreakers in Indonesia", but correctional facilities have various obstacles to undergoing a coaching, namely being overcrowded.(Fahriza, 2020)

This situation also has an impact on the prisoners who are in the Correctional Institution which we also know that there are quite a lot of prisoners in every cell occupied, the Ministry of Law and Human Rights as the organizer of the Indonesian correctional system, organizes a correctional system so that prisoners can improve themselves and not repeat themselves. the crime he committed, so that prisoners can be accepted back into the community, return to active roles in development and live naturally as a citizen through the training that will be carried out in Correctional Institution. (Tantaru, Taule, \& Ubwarin, 2021) For this reason, the Ministry of Law and Human Rights also takes a policy to prevent the spread of the corona virus in correctional institutions (prisons), state detention centers (rutan) and the Special Child Development Institution (LPKA) by issuing Minister of Law and Human Rights Regulation No. 24 of 2021 which was stipulated on June 30, 2021 as an amendment to the Ministerial Regulation no. 32 of 2020 concerning Terms and Procedures for Granting Assimilation, Conditional Release, Leave Before Release, and Conditional Leave for Prisoners and Children in the Context of Prevention and Control of the Spread of Covid-19. Given the increasing number of victims who died due to the Corona Virus outbreak.

Penitentiary is one of the law enforcement institutions that is the estuary of the criminal justice system which imposes imprisonment on the convict. In its development, the implementation of prison sentences for convicts does not carried out solely as an attempt to revenge and keep prisoners away from society, but rather a form of self-isolation from behind prison walls experiencing change to the form of correctional, namely making prisoners into human beings completely by focusing on coaching patterns such as personality development and independence. Along with the progress of a nation's civilization, the provision of criminal sanctions By fostering prisoners in Correctional Institutions in Indonesia, there is a change significantly. But in reality, the process of fostering prisoners based on the system correctional facilities are hampered by existing problems, such as poor conditions of detention cells overcapacity, cramped and very unfit. With the outbreak of the COVID-19 virus, problems regarding the condition of the Correctional Institution which are not adequate become a frightening specter for prisoners because it does not allow for social distancing between inmates in the Correctional Institution which makes it very easy the process of transmitting the COVID-19 virus between fellow prisoners. Institution Condition Correctional facilities that are not possible to prevent transmission 
of the COVID-19 virus 19 and on the basis of humanity, namely the fulfillment of human rights for prisoners who be considered by the Minister of Law and Human Rights of the Republic of Indonesia, Yasonna Laoly issued Regulation of the Minister of Law and Human Rights Number 10 Year 2020 Concerning Conditions for Granting Assimilation and Integration Rights for Prisoners and Children in the context of preventing and controlling the spread of COVID-19 as one of the how to reduce the risk of transmission of the COVID-19 virus in the Correctional Institution. (Yuliandhari, 2020)

The extension of the granting of assimilation rights is contained in the Regulation of the Minister of Law and Human Rights Number 24 of 2021 concerning Conditions and Procedures for Granting Assimilation, Conditional Release (PB), Leave Before Free (CMB), and Conditional Leave (CB) for Prisoners and Children in Order of Prevention and Control of the Spread of Covid-19. The Director General of Corrections, Reynhard Silitonga, stated that the extension was urgent because of the ongoing and very high potential for transmission of Covid-19 into correctional institutions (prisons), state detention centers (rutan) and the Special Child Development Institute (LPKA). "We have continued to carry out evaluations since the beginning of the pandemic in 2020, so these changes were made. Assimilation is the process of fostering prisoners and children carried out by assimilate them in community life. Inmates who are sent home are still under the supervision of the Correctional Center. That is, they are not allowed to leave the house so that it is hoped that there will be no more criminal acts when they get assimilated at home. In order to prevent sent home prisoners from committing crimes again, the role of the Village Head, RT and RW is also needed to carry out strict supervision and guidance. Of course, based on the Regulation of the Minister of Law and Human Rights No. 24 of 2021 concerning Terms and Procedures for Granting Assimilation, Conditional Release, Leave Prior to Release, and Conditional Leave for Prisoners and Children in the Context of Prevention and Control of the Spread of Covid-19. Not all prisoners who are in a correctional institution can obtain this assimilation, because there are conditions that must be met for prisoners who will obtain assimilation based on the Regulation of the Minister of Law and Human Rights No. 24 of 2021. From the background of these problems, the author will discuss the problem of how the requirements of the Minister of Law and Human Rights Regulation no. 24 of 2021 concerning Conditions and Procedures for Granting Assimilation, Conditional Release, Leave Before Release, and Conditional Leave for Convicts and Children in the Context of Prevention and Control of the Spread of Covid-19 and what are the consequences with the release of prisoners who have met the requirements to get this right of assimilation if The convict re-commits the crime after he is released from the correctional institution (lapas), state detention center (rutan) and/or the Child Special Guidance Institution (LPKA).

\section{Research Methods}

The method that the author uses in this research is qualitative research.The data used is secondary data consisting of primary legal materials, secondary legal materials and tertiary legal materials.Data collection in this study was conducted by conducting a literature study.In this case the researcher collects legal materials by reading, quoting, taking notes, 
and studying reading materials related to research problems, especially Regulation of the Minister of Law and Human Rights no.24 of 2021, amendments to Ministerial Regulation Number 32 of 2020 concerning Conditions and Procedures for Granting Assimilation, Conditional Release, Leave Prior to Release, and Conditional Leave for Convicts and Children in the Context of Prevention and Control of the Spread of Covid-19.The data that has been collected is stated in the form of a description. The data analysis used in this research is descriptive qualitative.

\section{Discussion and Results}

Terms and Procedures for Granting Assimilation, Conditional Release, Leave Before Release, and Conditional Leave for Prisoners and Children in the Context of Prevention and Control of the Spread of Covid-19

Correctional Institutions (Lapas) are state-owned institutions with the following functions: carry out coaching, and security of prisoners and children. Meanwhile, the State Detention Center (Rutan) serves as a place for treatment of suspects and defendants, or people who have not been convicted permanent legal force.Because of its limiting nature individual, the two institutions accommodate many people in one room making it a vulnerable location for the spread of COVID-19. In addition to their closed nature, prisons and detention centers in Indonesia are listed experiencing an overcrowding condition or an excess number of occupants compared to the institutional capacity.In December 2019, it was noted that prisons and detention centers in Indonesia experienced 100\% overcrowding. At that time same.

WHO recommended preventive measures to maintain social distance, wearing a mask, washing hands regularly is difficult, not even possible, carried out in prisons and detention centers that are overcrowded. Facility such as masks and clean water are also often not available. Therefore, the most effective steps to anticipate the spread of COVID-19 in Prisons and Rutan are reducing the population of prisoners and detainees. Overcrowded conditions complicate efforts to control COVID-19 in prisons and Prison. Therefore, the government through the Ministry of Law and Human Rights issues an assimilation policy (Permenkumham No 2020 Regarding Terms of Granting Assimilation and Integration Rights for Prisoners and Children in the Context of Prevention and Management spread of COVID-19). The policy, in general, contains: the policy of granting assimilation and integration rights for prisoners and detainees who are deemed to meet certain criteria, in order to Reduction of the occupants of detention centers and prisons.

Assimilation is a coaching process for prisoners and students correctional facilities carried out by mixing prisoners and children correctional education in community life.(PP No.31 th1999). Correctional Institution is an institution that is open specifically in carrying out further development of prisoners at the assimilation stage, namely with a criminal period of between to $2 / 3$ of the prison population. the period of imprisonment that must be served by the prisoner concerned.

An important part of the criminal system is to apply a sanction for the violator, its existence will provide direction and consideration as to what is 
wrong should be used as a sanction in a criminal act to enforce enactment of a norm or rule (M. Sholehuddin, 2003).Correctional institutions are places of guidance with the aim that prisoners can return to being good citizens of society who are aware of all their mistakes and can return to society with be a good human.Prison development is a system, so prisoner development has several components that work together related to one purpose (CI. Harsono HS, 1995).

The Indonesian government is one of those responding to the spread of COVID-19 in closed facilities such as prisons. Through the Ministry of Law and Human Rights, the Government of Indonesia issues a Ministerial Regulation Law and Human Rights (Permenkumham) Number 10 of 2020 concerning Terms Granting Assimilation and Integration Rights for Prisoners and Children.In Order of Prevention and Control of the Spread of COVID-19 (hereinafter referred to as the Assimilation Policy).In this regulation, the government recognizes that Correctional Institutions (Lapas), Guidance Institutions specifically for children (LPKA), and the State Detention Center (Rutan) is a closed place with a high occupancy rate so that it is vulnerable to the spread of COVID-19.

There are three conditions contained in the policy of granting assimilation These are 1) behave well and are not currently serving a sentence discipline in the last six months;2) actively participate in the program good coaching;3) has served half the sentence. Meanwhile, for Children, the provisions differ only in terms of the period review period (last three months) and have served a minimum sentence for three months.

The Assimilation Policy is implemented based on supporting evidence in the form of: photocopy of judge's decision and minutes of execution of court's decision; proof of payment of fines/subsidiaries;development progress report signed by the head of the prison, a copy of register F, a copy of the list of changes from the head of the prison and also a statement that the prisoner did not run away and did not violate the law from the prisoner.In addition, prisoners who will receive this program come from the recommendation of correctional officers.

During the Covid-19 Pandemic, which had previously been regulated regarding assimilation in Law number 10 of 2020 concerning Terms Granting Assimilation and Integration Rights for Prisoners and Children.In Order of Prevention and Control of the Spread of COVID-19.

That the handling of Covid-19 prevention and control for prisoners and children is based on the Regulation of the Minister of Law and Human Rights NO. 32 of 2020 concerning Terms and Procedures for Providing Assimilation, Conditional Release, Leave Before Release, and Conditional Leave for Convicts and Children in the Context of Prevention and Overcoming the spread of Covid-19, only reaching prisoners who have $2 / 3$ (two thirds) of their criminal term remaining and children remaining 1/2 (one half) of their criminal period until 30 June 2021, it is necessary to make changes to the Regulation of the Minister of Law and Rights Human Rights Number 32 of 2020 concerning Terms and Procedures for Granting Assimilation, Conditional Release, Leave Prior to Release, and Conditional Leave for Prisoners and Children in the Context of Prevention and Control of the Spread of Covid-19. Minister of Law and Human Rights Regulation No. 24 of 2021 dated June 30, 2021 changed: 
1. The provisions of Article 11 paragraph (3) are:

(1) Assimilation as referred to in Article 2 shall not be granted to prisoners who commit a crime:

a. narcotics, narcotic precursors, and psychotropics;

b. terrorism;

c. corruption;

d. crimes against state security;

e. serious human rights crimes;

f. other transnational organized crimes.

(2) Prisoners who commit crimes against narcotics, narcotic precursors, and psychotropic substances as referred to in paragraph (1) letter a only applies to convicts who are sentenced to a minimum imprisonment of 5 (five) years.

(3) In addition to the crime as referred to in paragraph (1), assimilation is not given to Convicts/Children who commit criminal acts:

a. murder as referred to in Article 339 and Article 340 of the Criminal Code;

b. theft with violence as referred to in Article 365 of the Criminal Law Act;

c. decency as referred to in Article 285 to Article 290 of the Criminal Code; or

d. decency towards Children as victims as referred to in Article 81 and Article 82 of Law Number 23 of 2002 concerning Child Protection as last amended by Law Number 17 of 2016 concerning Stipulation of Government Regulation in Lieu of Law Number 1 of 2016 concerning Second Amendment to Law Number 23 of 2002 concerning Child Protectionbecome law.

(4) In addition to the exceptions referred to in paragraph (3), assimilation is not granted to Convicts/Children who repeat a crime, as well as criminal acts committed previously have been sentenced and have obtained permanent legal force.

2. The provisions of Article 45 are amended to read as follows:

Article 45: This Ministerial Regulation applies to convicts whose sentence is $2 / 3$ (two thirds) of their criminal period and Children whose $1 / 2$ (one half) of their criminal period is until December 31, 2021.

The consequence is the release of convicts who have met the requirements for obtaining their right of assimilation if the convict re-commits the crime after them are released from the correctional institution (prison), state detention center (rutan) and the Special Child Development Institution (LPKA)

So, according to the Regulation of the Minister of Law and Human Rights No.24 of 2021, a new article has been stipulated that changes the contents of the previous article in the Regulation of the Minister of Law and 
Human Rights No.32 of 2020 considering the increasingly widespread and increasing number of victims who died and patients exposed to the corona virus outbreak as an anticipation of reducing prisoners in prisons (prisons), state detention centers (rutan) and the Special Child Development Institute (LPKA) so as to preventtransmission due to crowds contained in correctional institutions (prisons), state detention centers (rutan) and the Special Child Development Institute (LPKA).

As a result of the assimilation given or obtained by prisoners who have met the requirements for assimilation recipients, of course this ministerial regulation also cannot confirm whether after the release of the prisoner, this prisoner can become a truly good individual, not committing a similar crime again.what he has done or even repeats his actions or the same crime again or a new crime while carrying out assimilation at home, then to answer this, based on the Regulation of the Minister of Law and Human Rights No.24 of 2021, the assimilation will be revoked and the prisoner who has obtained the right of assimilation at home will continue to serve the remainder of his next sentence in accordance with the article that ensnared him and will be added to the next sentence of the crime he committed after obtaining assimilation at home.

This is also reinforced by a quote in an article by the Director General of Corrections Calling Assimilation Prisoners Acting in Few, Director General of Corrections at the Ministry of Law and Human Rights, Reynhard Silitonga, stated that in Indonesia the rate of convicts who repeat their crimes is very low compared to other countries, which is $0.2 \%$.Still from the same article, Director of Prisoners' Development and Production Job Training, Ministry of Law and Human Rights, Junaedi emphasized that assimilation means being released with the status of still prisoners, if they commit a violation, then the prisoner concerned can be put back in prison/detention center.Inmates who are sent home are still under the supervision of the Correctional Center.This means that they are not allowed to leave the house and if they return to commit a crime, the punishment will be increased.(DA, 2020)

\section{Conclusion}

Based on the description above, it can be concluded that to cope with the spread of the corona virus which is increasingly widespread and takes many lives and patients exposed to this virus, the Correctional Institution is one of the law enforcement institutions which is the estuary of criminal justice which imposes imprisonment on the convicts. then the Ministry of Law and Rights issued a policy for prisoners who were in correctional institutions (prisons), state detention centers (rutan) and the Special Child Development Institution (LPKA), namely assimilation at home with provisions based on the Regulation of the Minister of Law and Human Rights No. 24 of 2021 dated June 30, 2021 and for a prisoner who has met the requirements to obtain assimilation and has the right to obtain the right of assimilation at his home but if after obtaining the right of assimilation at home, he commits a crime again, the right of assimilation at home given to him will be revoked and the prisoner too will be withdrawn back to the correctional institution (lapas), state detention center (rutan) and the Special Child Development Institution (LPKA) to serve the remainder of his sentence 
plus a new sentence for the criminal act he committed after he received assimilation at home. 


\section{References}

Anwar, M. (2020, 5 1). Asimilasi Dan Kriminalitas Ditengah Psbb Pandemi Corona. Retrieved 9 28, 2021, from visione.co.id: http://ppm.unpam.ac.id/2020/05/01/asimilasi-dan-kriminalitasditengah-psbb-pandemi-corona/

DA, A. T. (2020, 5 7). Dirjen Pemasyarakatan Sebut Napi Asimilasi Berulah Jumlahnya Sedikit. Retrieved 7 18, 2021, from Hukum Online.com: https://www.hukumonline.com/berita/baca/lt5eb283f0eb87d/dirjenpemasyarakatan-sebut-napi-asimilasi-berulah-jumlahnyasedikit?page $=$ all/

Fahriza, R. (2020, 12 7). Optimalisasi Tugas Dan Fungsi Pembimbing Kemasyarakatan Dalam Upaya Pencegahan Overcrowded Di Lembaga Pemasyarakatan. Reformasi Hukum, 24(2)

Harsono HS. CI., Sistem Baru Pembinaan Narapidana, Jakarta: Djambatan, 1995

Kementerian Hukum dan HAM Republik Indonesia, Peraturan Menteri Hukum dan HAM Nomor 10 Tahun 2020 Tentang Syarat Pemberian Asimilasi dan Hak Integrasi Bagi Narapidana dan Anak Dalam Rangka Pencegahan dan Penanggulangan Penyebaran COVID-19, (Jakarta: Kementerian Hukum dan HAM, 2020)

Pane, M. D. (2021, 8 6). Virus Corona. Retrieved 9 28, 2021, from Alodokter.com: https://www.alodokter.com/virus-corona

Rosa, M. C. (2021, 7 03). PPKM Darurat Resmi Berlaku, Berikut Perbedaannya dengan PPKM Mikro. Retrieved 7 18, 2021, from Kompas.com:https://www.kompas.com/tren/read/2021/07/03/06300096 5/ppkm-darurat-resmi-berlaku-berikut-perbedaannya-dengan-ppkmmikro?page $=$ all

Sholehuddin, M. 2003,Sistem Sanksi Dalam Hukum Pidana, Rajawali. Pers

Tantaru, F., Taule, E. R., \& Ubwarin, E. (2021). Kajian Sosio-Yuridis Pembebasan Bersyarat dan Pemberian Asimilasi. SANISA: Jurnal Kreativitas Mahasiswa Hukum, 1(1),34-41. https://fhukum.unpatti.ac.id/jurnal/sanisa/article/view/515

Yuliandhari, S. A. (2020). Efektivitas Pembinaan Lembaga PemasyarakatanGuna Mencegah Terjadinya Residivis Asimilasi Di Era Pandemi Covid-19. National Conference For Law Studies

Peraturan Menteri Hukum dan Hak Asasi Manusia No. 24 Tahun 2021 perubahan atas Peraturan Menteri Hukum dan Hak Asasi Manusia No.32 tahun 2020

Peraturan Pemerintah tentang Pembinaan dan Pembimbingan Warga Binaan Pemasyarakatan. Peraturan Pemerintah No. 31 Tahun 1999 